\title{
Antimicrobial activity of enterocin obtained from Enterococcus durans on Shiga-like toxin-producing Escherichia coli
}

\author{
Natara Favaro Tosoni ${ }^{1}$ Hugo Felix Perini ${ }^{2}$ Márcia Regina Terra ${ }^{2}$ Marly Sayuri Katsuda ${ }^{3}$ \\ Márcia Cristina Furlaneto ${ }^{2}$ Luciana Furlaneto Maia $^{1}$ (D)
}

${ }^{1}$ Programa de Pós-graduação em Tecnologia de Alimentos, Universidade Tecnológica Federal do Paraná (UTFPR), Campus Campo Mourão/ Medianeira, 86036-370, Londrina, PR, Brasil. E-mail: lucianamaia@utfpr.edu.br. "Corresponding author.

${ }^{2}$ Programa de Pós-graduação em Microbiologia, Universidade Estadual de Londrina (UEL), Londrina, PR, Brasil.

${ }^{3}$ Universidade Tecnológica Federal do Paraná (UTFPR), Londrina, PR, Brasil.

ABSTRACT: Shiga-like toxin-producing Escherichia coli (STEC) is an important source of food contamination that presents risks to human health. Several industrial food processes eliminate this microorganism; however, these processes can alter the characteristics of the product. Alternative methods of preservation have been identified as an option to control these foodborne pathogens. The purpose of this study was to evaluate the action of bacteriocins produced by Enterococcus durans MF5 in STEC cells. Cell-free supernatant (CFS) containing enterocins from the MF5 isolate was tested over different time points $(6,18$, and $24 \mathrm{~h})$. Enterocins present in the crude CFS showed inhibition against STEC at all time points. In the investigation of cell integrity, using propidium iodide and fluorescence microscopy, considerable cell death was observed within $6 \mathrm{~h}$ of the cells being in contact with the enterocins, which was also observed at the 18 and $24 \mathrm{~h}$ time points. These results showed that the enterocins produced by the MF5 isolate have potential use in the control of STEC.

Key words: bacteriocin, spot-on lawn assay, STEC.

Atividade antimicrobiana de enterocina produzida por Enterococcus durans sobre Escherichia coli produtora de toxina Shiga-like

RESUMO: Escherichia coli, produtora de toxina Shiga-like (STEC), apresenta riscos à saúde humana, constituindo uma importante fonte de contaminação na indústria de alimentos. Diversos processos industriais eliminam esse microrganismo, contudo podem alterar as características do produto. Métodos alternativos de conservação tem sido uma opção para controlar esse microrganismo de alimentos. O objetivo desta pesquisa foi avaliar a ação de bacteriocinas produzidas por Enterococcus durans MF5 em células de E. coli STEC. Foram utilizados sobrenadante livre de células (CFS) contendo enterocina, nos tempos 6, 18 e 24 horas de incubação. A enterocina presente no CFS bruto apresentou inibição contra E. coli STEC em todos os tempos testados. Na observação da integridade celular utilizando iodeto de propídio e observação em microscópio de fluorescência, observou-se que em 6 h da célula em contato com a enterocina, já havia considerável morte celular, estendendo até os tempos de 18 e 24 horas. Os resultados obtidos mostraram que a enterocina produzida pelo isolado MF5 apresenta uso potencial no controle de E. coli STEC.

Palavras-chave: bacteriocina, ensaio spot-on lawn, STEC.

\section{INTRODUCTION}

Shiga-like toxin-producing Escherichia coli (STEC) is a foodborne pathogen, which forms a part of the normal microflora of the intestinal tract of warmblooded animals, including humans. Transmission occurs through consumption of food and/or water contaminated by fecal matter, from person to person, or direct contact with the feces of carriers (TORRESARMENDÁRIZ, 2016; FENG et al. 2016).

Shiga toxin-producing Escherichia coli is an emerging pathogen of great importance both to human health, owing to the severity of symptoms it causes, including death, and with negative effects on tourism, food industry, and export of products
(TORRES-ARMENDÁRIZ, 2016). Pathogenicity of this bacterium is associated with different virulence factors, including shiga toxin type 1 and type 2 (Stx 1 and Stx2); type 1 toxins are also produced by Shigella dysenteriae (PENNINGTON 2010; SÁNCHEZ et al. 2010). Another virulence factor is intimin, an adhesive factor associated with colonization processes involving destruction of the microvilli of the intestinal mucosa (SÁNCHEZ et al., 2010). These organisms can cause a variety of mild to severe symptoms, including watery diarrhea, bloody diarrhea (hemorrhagic colitis), and hemolytic uremic syndrome (HUS) (MENARD et al., 2004).

Several traditional methods of food preservation based on heat treatments, such as 
pasteurization and sterilization, are effective in the control of STEC. However, these processes have negative effects on the final product, such as the loss or reduction of nutrients, or alteration of sensorial characteristics (SAUCEDA, 2011). Furthermore, these methods are not applicable to the preservation of raw products, such as meats and milk (NAJIM \& DAHER, 2014). Alternatives to traditional methods of preservation have been proposed, and can be used alone or in combination to contribute to the preservation and safety of food. Examples of alternative treatments include the use of essential oils (SOLORZANOSANTOS \& MIRANDA-NOVALES, 2012), organic acids, and bacteriocins (peptides) (GARCÍA et al. 2010; ROLDÁN et al. 2011).

Compared to chemical preservatives, bacteriocins and bacteriocin-producing bacteria have been proposed as a safe and effective alternative for the control of foodborne pathogens (GÁLVEZ, et al., 2010; LUCERA et al., 2012).

Bacteriocins are ribosomally-synthesized antimicrobial proteins/peptides produced by several bacterial genera, and can kill or inhibit the growth of other bacteria either of the same species or across genera (broad spectrum of activity). However, bacteriocins from lactic acid bacteria (LAB) are generally not active against $E$. coli or other gramnegative bacteria (COTTER et al. 2013).

Enterocins are a class of cationic bacteriocins produced by Enterococcus and are active against gram-negative and gram-positive bacteria; they are resistant to a great range of temperatures and $\mathrm{pH}$ levels, apart from being easily destroyed by digestive proteases. Moreover, they present a broad spectrum of activity against gram-positive and gramnegative microorganisms (MARTÍNEZ-BUENO \& GÁLVEZ, 2017), which makes them of great technological interest.

The present research evaluated the inhibitory action of enterocins against serotypes of STEC.

\section{MATERIALS AND METHODS}

\section{Bacterial isolates}

Enterococcus durans MF5 was isolated from whey, harbored enterocin-encoding genes (entA, ent $\mathrm{B}$, and ent $\mathrm{X}$ ) and bacteriocin-producing (data not shown). The strain belongs to the Laboratory of Basic and Applied Microbiology of the Federal University of Technology - Paraná (Londrina, PR, Brazil).

Shiga toxin-producing Escherichia coli was obtained from the bacterial collection of Medical Microbiology Laboratory at the Universidade
Estadual de Londrina (Londrina, PR, Brazil). Polymerase chain reaction (PCR) confirmed the presence of $s t x 1$ and $s t x 2+$ genes.

Stock cultures were stored at $-20{ }^{\circ} \mathrm{C}$, in Brain Heart Infusion (BHI) Broth (AcumediaNeogen) supplemented with $20 \%$ (v/v) glycerol (Gibco).

\section{Hemolytic activity}

The hemolytic activity of the Enterococcus isolate was examined on blood agar supplemented with 5\% sheep blood; $10 \mu \mathrm{L}$ of an overnight culture of Enterococcus was inoculated onto blood agar plates, which were incubated at $37^{\circ} \mathrm{C}$ for $48 \mathrm{~h}$. Clear colonies were considered hemolytic.

Screening for enterocin activity against enterohemorrhagic Escherichia coli

Screening for enterocin activity was performed using the spot-on lawn assay (OGAKI, et al., 2016). One milliliter of chloroform was deposited on the covers of plates of $E$. durans MF5 strains, previously incubated on BHI agar (Himedia) at $37^{\circ} \mathrm{C}$ for $24 \mathrm{~h}$, and closed for $20 \mathrm{~min}$; the plates were subsequently opened to allow the residual chloroform to evaporate. The number of enterohemorrhagic Escherichia coli (STEC) was adjusted to $1 \times 10^{9}$ cells $/ \mathrm{mL}$, using the McFarland nephelometric scale, with $1 \times 10^{8}$ cells $/ \mathrm{mL}$ inoculated into soft $\mathrm{BHI}$ agar $(0.8 \%)$, which was poured onto the $E$. durans MF5 plates forming an overlay. Plates were then incubated at $37{ }^{\circ} \mathrm{C}$ for $24 \mathrm{~h}$; bacteria were considered bacteriocin-producers if inhibition zones were evident around the colonies.

Determination of bacteriocin production and antimicrobial activity

The cell free supernatants (CFSs) of the previously selected isolates were collected, following a modified version of that described by AMMOR et al., (2006). Enterococcus durans MF5 was adjusted to 0.5 McFarland standard in Man-Rogosa Sharpe (MRS) broth (Acumedia-Neogen), before being incubated at $37^{\circ} \mathrm{C}$ at $180 \mathrm{rpm}$, for $24 \mathrm{~h}$. The CFS was obtained by centrifugation at $12,000 \times g$ for $15 \mathrm{~min}$. To avoid the inhibitory effects of organic acids and hydrogen peroxide $\left(\mathrm{H}_{2} \mathrm{O}_{2}\right)$, the $\mathrm{pH}$ of the CFS was adjusted to 6.5 with $1 \mathrm{M} \mathrm{NaOH}$, before catalase $(0.5$ $\mathrm{mg} / \mathrm{mL}$ ) was added. The CFS was filtered through a $0.22 \mu \mathrm{m}$ pore size filter (Millipore, Merck). The antimicrobial activity of the CFS was quantified through a microtiter plate assay. Briefly, overnight cultures of STEC were adjusted to $0.5 \mathrm{McF}$ arland standard in $\mathrm{BHI}$, before $100 \mu \mathrm{L}$ was transferred into 
each well of a 96-well polystyrene microtiter plate, together with $100 \mu \mathrm{L}$ of CFS-containing bacteriocins; for the control, $100 \mu \mathrm{L}$ of MRS broth was added to each well in place of the CFS-containing bacteriocins. Plates were incubated at $37^{\circ} \mathrm{C}$ for 6,18 , and $24 \mathrm{~h}$. Absorbance was measured at $540 \mathrm{~nm}$ (O.D.540 nm).

\section{Fluorescence microscopy}

Coverslips $(13 \mathrm{~mm})$ were placed in the wells of 24-well plates containing $500 \mu \mathrm{L}$ overnight cultures of STEC ( $0.5 \mathrm{McF}$ arland standard) in BHI, together with $500 \mu \mathrm{L}$ of CFS-containing enterocins; for the control, $500 \mu \mathrm{L}$ of MRS broth was added to each well in place of the CFS-containing enterocin. Plates were incubated at $37{ }^{\circ} \mathrm{C}$ for 6,18 , and $24 \mathrm{~h}$. Samples were washed twice with PBS and incubated with $30 \mu \mathrm{g} / \mathrm{mL}$ of propidium iodide (PI, reconstituted in PBS) (Sigma-Aldrich, Germany), at room temperature in the dark for $15 \mathrm{~min}$ (JOHNSON; CRISS, 2013). After incubation, the staining solution was aspirated, the coverslips were washed with PBS, and the cells were viewed using an epifluorescence microscope (Zeiss, Germany). Cells with a reddish color were considered non-viable.

\section{Statistical analysis}

Data were evaluated using one-way ANOVA and Tukey's test considering $\mathrm{p}<0.05$ as significant to establish significant differences between the antimicrobial activity of the isolates and the control.

\section{RESULTS AND DISCUSSION}

The use of enterocins to successfully inhibit pathogenic microorganisms in food products has resulted in interest in novel tests and studies related to their antimicrobial activity, production, and characterization, which is necessary for the development of new strategies in the control of food contamination.

The development of biopreservation technologies with $\mathrm{LAB}$ and/or their metabolites represents protection of food against microbial contamination through the bacterial production of several anti-microbial substances including organic acids, hydrogen peroxide, and bacteriocins (PERIN et al., 2013).

In this study, we used the enterocin called MF5, produced by the E. durans MF5 isolate. In the screening test, the MF5 isolate showed antimicrobial activity against STEC, characterized by the clear zone around the colony (Figure 1A), indicative of cell death. The activity of the CFS was not influenced by the neutralized CFS; the elimination of hydrogen peroxide produced the same results, demonstrating the antimicrobial activity was due to CSF and not hydrogen peroxide. No hemolytic

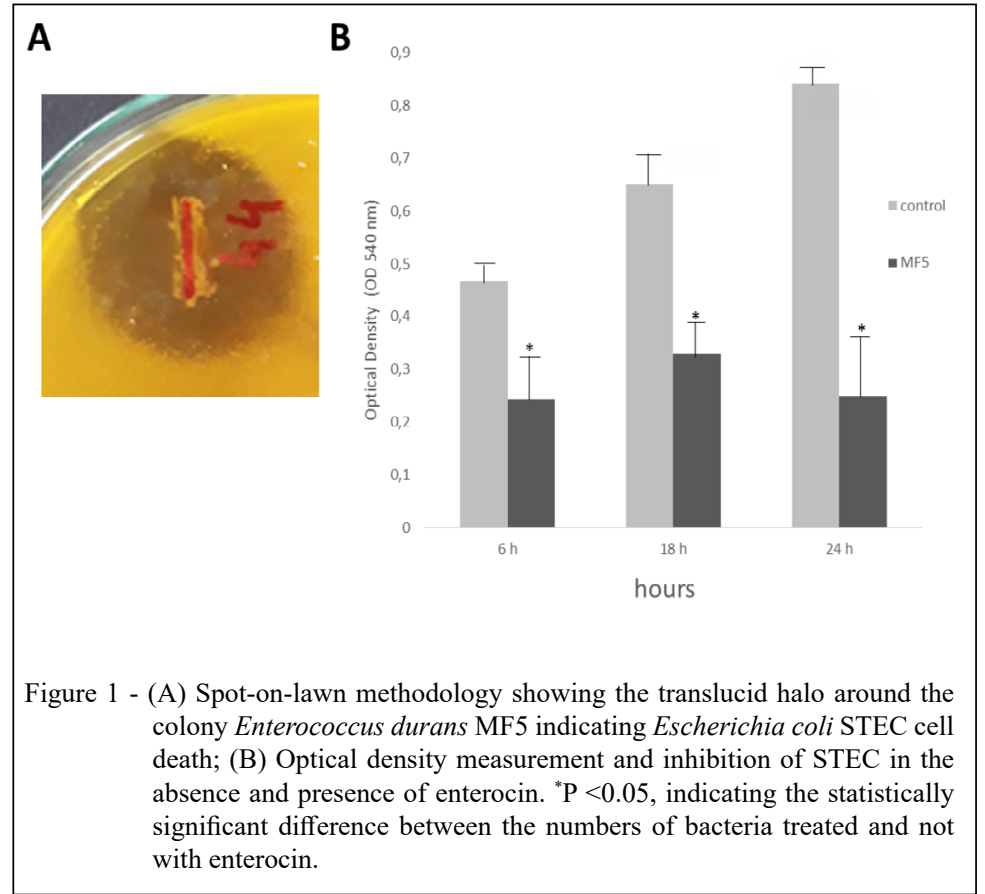

Ciência Rural, v.49, n.9, 2019. 
activity was observed under the test conditions. Hemolysin production may increase the risk of enterococci infections.

Cellular growth of STEC, and its inhibition by enterocins, was measured by optical density (Figure 1B). We observed that the cell growth of the control remained constant up to $24 \mathrm{~h}$ of testing; in contrast, in the presence of enterocins, we observed inhibition within $6 \mathrm{~h}$ of treatment, remaining up to $24 \mathrm{~h}$. That is, the decrease of initial STEC growth with CFS was permanent and affected the cellular development even after 18 and $24 \mathrm{~h}$.

For STEC, enterocin produced by $E$. durans MF5 showed a significant reduction $(\mathrm{p}<0.05)$ in cell viability at 6,18 and $24 \mathrm{~h}$ incubation, when compared to control; however, there was no significant difference between the incubation times when the cells were treated with enterocin.

It is worth mentioning that the enterocins used in this study were free in the CFS, i.e., they were not concentrated and purified. Furthermore, the cellular concentration of STEC was at higher concentrations $\left(1 \times 10^{8} \mathrm{CFU} / \mathrm{mL}\right)$ than those reported in foods, suggesting that at lower concentrations, the efficiency of antagonism may be greater.
To confirm the antimicrobial action on STEC, following exposure to enterocin MF5, the cells were treated with PI and observed immediately through fluorescence microscopy. Figure 2 shows representative images of the effect of the enterocins on STEC. Resultant images confirmed the loss of cellular integrity of STEC exposed to enterocins, characterized by a reddish coloration. In the absence of enterocins (control) there are a limited number of dead cells observed, while the addition of enterocins resulted in clustering of cells and a larger number of dead cells (reddish color).

Propidium iodide is a membrane impermeant intercalator DNA that only stains cells with compromised membrane integrity, presenting with the reddish coloration (LEWENZA et al., 2018; ROCHA et al., 2019). Our data shows the intensity of the reddish color in the first $6 \mathrm{~h}$ of STEC in contact with the enterocins (Figure 2); therefore, indicating the penetration of PI. These data corroborated the OD values observed in figure $1 \mathrm{~B}$. The reddish color intensified with $24 \mathrm{~h}$ of treatment, emphasizing the cell death of STEC.

Enterocins, like most bacteriocins, mainly target the cytoplasmic membrane of cells,

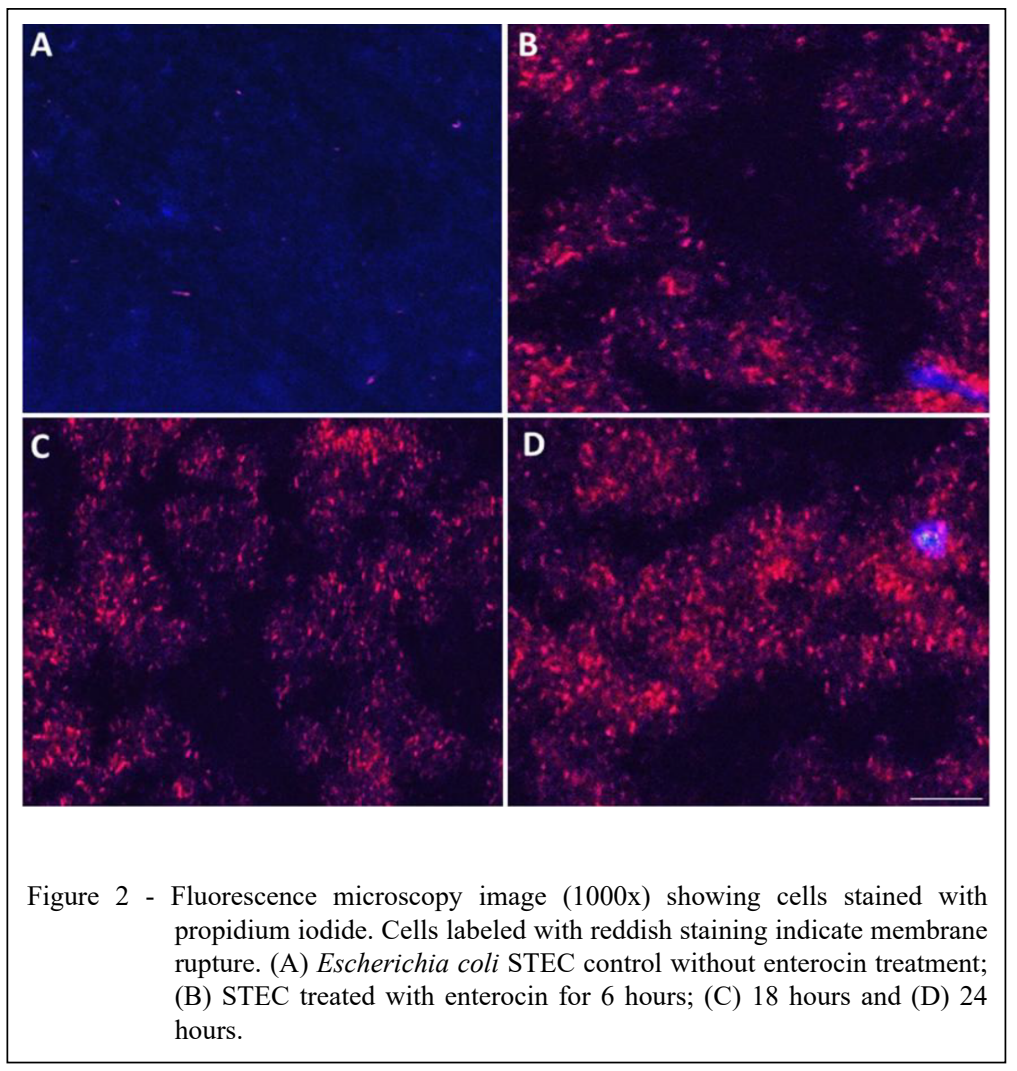

Ciência Rural, v.49, n.9, 2019. 
forming pores which affects the transmembrane potential and/or the $\mathrm{pH}$ gradient, and results in the leakage of intracellular molecules crucial for cellular maintenance (CLEVELAND et al., 2001).

Aside from its antimicrobial activity, other properties that make enterocins a promising food preservative are their sensitivity to proteolytic enzymes, thermal stability, and maintenance of antimicrobial activity after storage at refrigeration temperature (data not shown). In addition, our results showed the inhibitory activity of CFS to be independent of the addition of chelators such as EDTA, SDS, or triton; this is contrary to studies that reported these agents to be necessary for the functioning of bacteriocins against gram-negative bacteria (DES FIELD et al., 2017).

While E. faecium and E. faecalis are known producers of enterocins, E. hirae, E. mundtii, and $E$. durans have been identified as potential producers (JAOUANI et al., 2014).

Many of these enterocins have been tested in various food products, targeting gram-positive and gram-negative pathogens such as Listeria monocytogenes, Listeria inoccua, Bacillus cereus, Staphylococcus aureus, Clostridium sp, Klebsiella sp, Acinetobacter sp, and Pseudomonas sp (KHAN et al., 2010; ROCHA et al., 2019).

Only two bacteriocins produced by LAB, nisin and pediocin, are commercially used as food preservatives. However, these bacteriocins are not active against gram-negative bacteria (CALO-MATA et al., 2008; HAMMAMI et al., 2010). Therefore, it is necessary to characterize additional bacteriocins produced by other LAB genera and elucidate their potential application in food safety.

Several authors have reported the difficulty of inhibition of gram-negative bacteria by bacteriocins; AHMADOVA et al (2013) and ACUÑA and BARROS-VELÁZQUEZ (2015) did not observe an inhibitory effect by purified enterocins against strains of E. coli and Salmonella. ALAKOMI et al. (2003) and YILDIRIM et al. (2014) reported the antagonistic action of the enterocin KP against E. coli O157:H7 and Salmonella only when the enterocins were combined with EDTA or sodium tripolyphosphate. These reports differ from the results obtained in this study, where the action of the enterocin MF5 on STEC was observed without the addition of an ion chelator. This indicated that the enterocin produced by our isolate has a more satisfactory inhibitory activity.

One hypothesis explaining the difficulty of action of bacteriocins against gram-negative bacteria is that involving the presence of lipopolysaccharides (LPS) anchored in the outer membrane of the microorganisms (ANANOU et al., 2010; MUÑOZ et al., 2007). The outer membrane acts as a permeability barrier to the action of antimicrobial compounds, preventing the penetration of bacteriocins, and making it difficult to bind to the site of action (YETHON \& WHITFIELD, 2001; FIELD et al., 2016).

Nevertheless, it is worth mentioning that in this study we used enterocin without concentration or purification, we obtained promising results. Other studies have also reported the efficacy of unpurified enterocins against gram positive bacteria (CAMARGO et al. 2016; AL ATYA et al. 2016; ROCHA et al. 2019).

Here, we have shown that enterocins present in the CFS of E. durans MF5 showed inhibitory activity against STEC, and the results are very promising, since our tests were performed with enterocins diluted in the culture medium supernatant; we proposed that the concentration and purification of the same enterocins will provide enhanced results in the reduction of food pathogens. Results of this study may have important implications for the development and implementation of new strategies to control enterohemorrhagic Escherichia coli.

\section{ACKNOWLEDGEMENTS}

This work was supported by Fundação Araucária/ Governo do Paraná - Brazil, PROPPG/ UTFPR. This study was financed in part by the Coordenação de Aperfeiçoamento de Pessoal de Nível Superior - Brasil (CAPES) - Finance Code 001.

\section{DECLARATION OF CONFLICT OF INTERESTS}

The authors declare that they have no conflict of interest. The founding sponsors had no role in the design of the study, nor in the data collection, analyses, or interpretation of data, the writing of the manuscript, nor the decision to publish the results.

\section{AUTHORS' CONTRIBUTIONS}

NFT, HFP, MRT and MSK carried out the experiments; MCF and LFM wrote and edited the manuscript; LFM designed the project. All authors read and approved the final manuscript.

\section{REFERENCES}

ACUÑA, L.; BARROS-VELÁZQUEZ, J. Inhibitory Effect of the Hybrid Bacteriocin Ent35-MccV on the Growth of Escherichia coli and Listeria monocytogenes in Model and Food Systems. Food Bioprocess Technol, v.8, p.1063, 2015. Available from: <https:// link.springer.com/article/10.1007/s11947-015-1469-0>. Accessed: Mar. 22, 2016. doi: 10.1007/s11947-015-1469-0. 
AHMADOVA, A. et al. Evaluation of antimicrobial activity, probiotic properties and safety of wild strain Enterococcus faecium AQ71 isolated from Azerbaijani Motal cheese. Food Control, v.30, p.631-641, 2013. Available from: <https://www.sciencedirect. com/science/article/pii/S0956713512004574?via\%3Dihub>. Accessed: Mar. 12, 2015. doi: 10.1016/j.foodcont.2012.08.009.

ALAKOMI H.L. et al. Effect of EDTA on Salmonella enterica serovar Typhimurium involves a component not assignable to lipopolysaccharide release. Microbiology, v.149, p.2015-2021, 2003. Available from: <https://mic.microbiologyresearch.org/ content/journal/micro/10.1099/mic.0.26312-0>. Accessed: Mar. 10, 2017. doi: 10.1099/mic.0.26312-0.

AL ATYA, A. K. et al. Anti-MRSA activities of enterocins DD28 and DD93 and evidences on their role in the inhibition of biofilm formation. Front Microbiol. v.7p. 817, 2016. Available from: $<$ https://www.frontiersin.org/articles/10.3389/fmicb.2016.00817/ full $>$. Accessed: Mar. 7, 2019. doi:10.3389/fmicb.2016.00817.

AMMOR, L, et al. Antibacterial activity of lactic acid bacteria against spoilage and pathogenic bacteria isolated from the same meat small-scale facility: 1 -Screening and characterization of the antibacterial compounds. Food Control. v.17, Issue 6, June 2006, p.454-461. Available from: $<$ https://www.sciencedirect.com/ science/article/pii/S0956713505000551>. Accessed: Feb. 2, 2019. doi: 10.1016/j.foodcont.2005.02.007.

ANANOU, S. et. al. Effect of combined physico-chemical treatments based on enterocin AS-48 on the control of Listeria monocytogenes and Staphylococcus aureus in a model cooked ham. Food Control, n.21, p.478-486, 2010. Available from: $\quad<$ https://www.sciencedirect.com/science/article/pii/ S0956713509002254?via\%3Dihub>. Accessed: Mar. 12, 2015. doi: 10.1016/j.foodcont.2009.07.010.

CALO-MATA, P., et al. Current applications and future trends of lactic acid bacteria and their bacteriocins for the biopreservation of aquatic food products. Food and Bioprocess Technology, v.1, p.43-63, 2008. Available from: <https://link.springer.com/ article/10.1007/s11947-007-0021-2>. Accessed: Mar. 12, 2015. doi: 10.1007/s11947-007-0021-2.

CAMARGO, A. C. et al. In vitro evaluation of bacteriocins activity against Listeria monocytogenes biofilm formation. Appl Biochem Biotechnol, v.178, p.1239-1251, 2016. Available from: $<$ https:// medes.com/publication/128267>. Accessed: Mar. 17, 2017. doi: 10.1016/j.ram.2017.04.011.

CLEVELAND, J. et al. Bacteriocins: safe, natural antimicrobials for food preservation. Int. J. Food Microbiol. v.71,p.1-20, 2001. Available from: <https://www.sciencedirect.com/science/article/ pii/S0168160501005608?via\%3Dihub>. Accessed: Mar. 12, 2015. doi:10.1016/S0168-1605(01)00560-8.

COTTER, P. D. et al. Bacteriocins: a viable alternative to antibiotics? Nature Reviews Microbiology, v.11, p.95105, 2013. Available from: <https://www.ncbi.nlm.nih.gov/ pubmed/16205711>. Accessed: Apr. 12, 2016. doi:10.1038/ nrmicro1273.

DES FIELD et al. Nisin in combination with cinnamaldehyde and EDTA to control Growth of Escherichia coli Strains of Swine Origin. Antibiotics. v.6, p.35, 2017. Available from: <https:// www.mdpi.com/2079-6382/6/4/35>. Accessed: Jun. 20, 2019. doi: 10.3390/antibiotics6040035.
FENG, P. et al. 2016. Diarrheagenic Escherichia coli. Bacteriological Analytical Manual. Chapter 4A. February 2011, updated June 2016. U.S. Department of Health and Human Services. U.S. Food and Drug Administration.

FIELD, D. et al. In vitro activities of nisin and nisin derivatives alone and in combination with antibiotics against Staphylococcus biofilms. Front Microbiol. v.7, p.508, 2016. Available from: <https://www.ncbi.nlm.nih.gov/pubmed/27148197>. Accessed: Jun. 19, 2019. doi: 10.3389/fmicb.2016.00508.

GÁLVEZ, A. et al. Microbial antagonists to food-borne pathogens and biocontrol. Current Opinion in Biotechnology. v.21, p.142148, 2010. Available from: <https://www.ncbi.nlm.nih.gov/ pubmed/17614151>. Accessed: Mar. 12, 2015. doi: 10.1016/j. ijfoodmicro.2007.06.001

GARCÍA P. et al. Food biopreservation: promising strategies using bacteriocins, bacteriophages and endolysins. Trends in Food Science \& Technology. v21, p.373-382, 2010. Available from: $\quad<\mathrm{https}: / / \mathrm{www}$. sciencedirect.com/science/article/abs/pii/ S0924224410001275>. Accessed: Apr. 11, 2019. doi:10.1016/j. tifs.2010.04.010.

HAMMAMI, R. et al. BACTIBASE second release: a database and tool platform for bacteriocin characterization. BMC Microbiology, 10, p.22, 2010. Available from: <https://bmcmicrobiol. biomedcentral.com/articles/10.1186/1471-2180-10-22>. Accessed: Apr. 11, 2019. doi: 10.1186/1471-2180-10-22.

JOHNSON, M.B. \& CRISS, A.K. Fluorescence microscopy methods for determining the viability of bacteria in association with mammalian cells. J Vis Exp, 79:p.1-9, 2013. Available from: $<$ https://www.jove.com/video/50729/fluorescence-microscopymethods-for-determining-viability-bacteria $>$. Accessed: Mar. 7, 2019. doi: $10.3791 / 50729$.

JAOUANI, I. et al. High inhibition of Paenibacillus larvae and Listeria monocytogenes by Enterococcus isolated from different sources in Tunisia and identification of their bacteriocin genes. Letters in Applied Microbiology, 59, 17-25; 2014. Available from: <https:// onlinelibrary.wiley.com/doi/epdf/10.1111/lam.12239>. Accessed: Oct. 22, 2017. doi: 10.1111/lam.12239.

KHAN, H. et al. Enterocins in food preservation. Int $\mathbf{J}$ Food Microbiol, n.141, v.1-2, p.1-10, 2010. Available from: $\quad<\mathrm{https} / /$ www.sciencedirect.com/science/article/pii/ S0168160510001170?via\%3Dihub>. Accessed: Oct. 22, 2017. doi:10.1016/j.ijfoodmicro.2010.03.005

LEWENZA S, et al. Pseudomonas aeruginosa displays a dormancy phenotype during long-term survival in water. PLoS One. v.13:e0198384, 2018. Available from: <https://www.ncbi.nlm.nih. gov/pmc/articles/PMC6147739/>. Accessed: Jun. 19, 2019. doi: 10.1371/journal.pone.0198384.

LUCERA, A., et al. Food applications of natural antimicrobial compounds. Front. Microbiol, v. 3, p. 287; 2012. Available from: $<$ https://www.frontiersin.org/articles/10.3389/fmicb.2018.00547/ full\#B30>. Accessed: Jun. 19, 2019. doi: 10.3389/ fmicb.2012.00287.

MARTÍNEZ-BUENO, M.; GÁLVEZ, A. Effect of combined physico-chemical treatments based on enterocin AS-48 on the control of Listeria. Food Control, v.21, n. 4, p.478-486, 2017. Available from: <https://onlinelibrary.wiley.com/doi/full/10.11 
11/j.1365-2672.2004.02276.x> Accessed: Dec. 02, 2018. doi: 10.1111/j.1365-2672.2004.02276.x.

MENARD, L. P. et al. Expression, purification and biochemical characterization of enteroaggregative Escherichia coli heat-stable enterotoxin 1. Protein Expression and Purification, v.33, p.223231, 2004. Available from: <https:/www.sciencedirect.com/ science/article/pii/S1046592803002961>. Accessed: Feb. 02, 2019. doi: 10.1016/j.pep.2003.09.008.

MUÑOZ, A. et al. Inhibition of Staphylococcus aureus in dairy products by enterocinAS-48 produced in situ and ex situ: Bactericidal synergism with heat. International Dairy Journal n.17,p.760-769,2007. Available from: <https://www.sciencedirect. com/science/article/abs/pii/S0958694606002196?via\%3Dihub>. Accessed: Oct. 22, 2017. doi: 10.1016/j.idairyj.2006.09.006

NAJIM, N. H.; DAHER, N. A. The synergistic bactericidal effects of bacteriocin and pressurization against E.coli $\mathrm{O} 157: \mathrm{H} 7$ in raw milk. The Iraqi Journal of Veterinary Medicine. 38(1): 15 $-23,2014$. Available from: $<$ http://jcovm.uobaghdad.edu.iq/index. php/Iraqijvm/article/view/114>. Accessed: Apr. 11, 2019.

OGAKI, M.B. et al. Screening of the enterocin-encoding genes and antimicrobial activity in Enterococcus species. J Microbiol Biotechnol. v.26, p. 1026-1034, 2016. Available from: $<$ http://www. jmb.or.kr/submission/Journal/026/JMB026-06-05_FDOC_1.pdf $>$. Accessed: Dec. 12, 2016. doi: 10.4014/jmb.1509.09020.

PENNINGTON H.. Escherichia coli O157. Lancet. v.376, p.1428-1435, 2010. Available from: <https://www.sciencedirect. com/science/article/pii/S0140673610609634> Accessed: Dec. 12 , 2016. doi: 10.1016/S0140-6736(10)60963-4.

PERIN L, et al. Antimicrobial activity of the Nisin Z producer Lactococcus lactis subsp. lactis Lc08 against Listeria monocytogenes in skim milk. Arq. Bras. Med. Vet. Zootec., 65(5):1554-1560, 2013. Available from: $<$ http://www.scielo.br/scielo.php?pid=S010209352013000500037\&script $=$ sci arttext. $>$. Accessed: Mar. 12, 2015. doi: 10.1590/S0102-09352013000500037.

ROCHA, K.R., et al. Inhibitory effect of bacteriocins from enterococci on developing and preformed biofilms of Listeria monocytogenes, Listeria ivanovii and Listeria innocua. World $\mathbf{J}$ Microbiol Biotechnol, v.35, p.96, 2019. Available from: <https:// link.springer.com/article/10.1007/s11274-019-2675-0\#citeas $>$. Accessed: Jun. 21, 2019. doi: 10.1007/s11274-019-2675-0>.

ROLDÁN M.L., et al. Efecto inhibidor de Lactobacillus casei 206/1 contra Escherichia coli O157:H7. Rev. Soc. Ven. Microbiol. v.31, p.37-41, 2011. Available from: <https://www.redalyc.org/ articulo.oa?id=199421829008>. Accessed: Apr. 2, 2019. doi: $25562011000100008 \& \operatorname{lng}=$ es.

SÁNCHEZ, S. et al. Clinical and pathogenic aspects of infections due to Escherichia coli $\mathrm{O} 157: \mathrm{H} 7$ and other verocytotoxigenic E. coli. Enferm. Infecc. Microbiol. Clin. v.28, p.370-374, 2010. Available from: < https://europepmc.org/abstract/med/19664858>. Accessed: Feb 21, 2019. doi: 10.1016/j.eimc.2009.06.009.

SAUCEDA, E.N.R. Uso de agentes antimicrobianos naturales en la conservación de frutas y hortalizas. Ra Ximhai, v.7, p.153-170, 2011. Available from: <http:/www.uaim.edu.mx/webraximhai> Accessed: Feb. 21, 2019. doi: 10.35197/rx.07.01.2011.14.er.

SOLORZANO-SANTOS, F.; MIRANDA-NOVALES, M.G Essential oils from aromatic herbs as antimicrobial agents. Curr. Opin. Biotechnol. v.23, p.136-141, 2012. Available from: $\quad<$ https://www.sciencedirect.com/science/article/abs/pii/ S0958166911006732>, Accessed: Feb. 21, 2019. doi: 10.1016/j. copbio.2011.08.005.

TORRES-ARMENDÁRIZ, V. et al. Interactions between Escherichia coli $\mathrm{O} 157: \mathrm{H} 7$ and food plants. Has this bacterium developed internalization mechanisms? Rev. Mex. Fitopatol.v.34, p. 64-83, 2016. Available from: <https://www.redalyc.org/ html/612/61243205004/>. Accessed: Mar. 17, 2019. doi: 10.18781/R.MEX.FIT.1507-4

YETHON, J. A.; WHITFIELD, C. Lipopolysaccharide as a target for the Development of Novel Therapeutics in Gram-Negative Bacteria. Current Drug Targets - Infectious Disorders, v.1, 2001. Available from: <https://www.ingentaconnect.com/content/ben/ cdtid $>$. Accessed: Mar. 01, 2017. doi: 10.2174/1568005014606143.

YILDIRIM, Z. et. al. Inhibitory effect of enterocin KP in combination with sublethal factors on Escherichia coli O157:H7 or Salmonella Typhimurium in BHI broth and UHT milk. Turk Journal Biol, v.38, p.412-419, 2014. Available from: <http:// journals.tubitak.gov.tr/biology/issues/biy-14-38-3/biy-38-3-131310-69.pdf>. Accessed: Mar. 01, 2017. doi: 10.3906/biy-1310-69. 